\title{
Rethinking the Study of Electoral Politics in the Developing World: Reflections on the Indian Case*
}

\author{
Adam Auerbach \\ aauerba@american.edu \\ Jennifer Bussell \\ jbussell@,berkeley.edu \\ Simon Chauchard \\ s.p.a.chauchard@,fsw.leidenuniv.nl \\ Francesca Jensenius \\ f.r.jensenius@stv.uio.no \\ Gareth Nellis \\ gnellis@ucsd.edu \\ Mark Schneider \\ mark.allan.schneider@gmail.com \\ Neelanjan Sircar \\ neelanjan.sircar@ashoka.edu.in \\ Pavithra Suryanarayan \\ psuryan1@jhu.edu
}

\footnotetext{
* Corresponding author: Milan Vaishnav, Carnegie Endowment for International Peace, mvaishnav@ceip.org. This article is the product of a workshop on "Rethinking Electoral Politics in India," hosted by the Carnegie Endowment for International Peace in September 2016 with financial support from the Hurford Foundation. We thank Devesh Kapur and Irfan Nooruddin for constructive feedback at this workshop. The authors are grateful to Rachel Osnos for helping organize the workshop and Rebecca Brown, Matthew Lillehaugen, Megan Maxwell, and Jamie Hintson for editorial and research assistance. We thank Pradeep Chhibber, Devesh Kapur, Ashutosh Varshney, the editor, and three anonymous reviewers for incisive comments on earlier drafts. All errors are our own.
} 


\author{
Tariq Thachil \\ thachil@sas.upenn.edu \\ Milan Vaishnav \\ mvaishnav@ceip.org \\ Rahul Verma \\ rahulverma@,cprindia.org \\ Adam Ziegfeld \\ awz@temple.edu
}

\begin{abstract}
In the study of electoral politics and political behavior in the developing world, India is often considered to be an exemplar of the centrality of contingency in distributive politics, the role of ethnicity in shaping political behavior, and the organizational weakness of political parties. Whereas these axioms have some empirical basis, the massive changes in political practices, the vast variation in political patterns, and the burgeoning literature on subnational dynamics in India mean that such generalizations are not tenable. In this article, we consider research on India that compels us to rethink the contention that India neatly fits the prevailing wisdom in the comparative politics literature. Our objective is to elucidate how the many nuanced insights about Indian politics can improve our understanding of electoral behavior both across and within other countries, allowing us to question core assumptions in theories of comparative politics.
\end{abstract}




\section{Word Count (including footnotes and bibliography): 9,889}

\section{Introduction}

The study of electoral politics and political behavior across the developing world has grown into a substantial body of scholarship over the past several decades. A hallmark of this literature has been to revise models first developed to explain the politics of advanced industrial countries. While it would be unwise to speak of a unified "consensus" that has materialized out of this rich and diverse scholarship, a set of conventional wisdoms has emerged that structure our understanding of electoral dynamics in the developing world. In particular, three pieces of received wisdom stand out.

First, electoral politics in the developing world is seen to be dominated by various forms of "distributive politics" (Stokes et. al 2013), which stand in marked contrast with programmatic politics linked to tax-and-transfer policies. Prevailing notions of distributive politics are often premised on the idea of quid pro quo contingent exchange, whereby voters select leaders based on targeted benefits and leaders, in turn, deliver these benefits to voters. The commitment problems governing such discretionary exchanges require parties to deploy local brokers who monitor electoral compliance. The distribution of promised goods is typically understood to take place during elections, leading to a focus on campaign season "vote-buying" as the dominant form of distributive politics (Stokes 2005; Nichter 2008).

A second, related element of the received wisdom is that ethnicity is one of the most-if not the most - crucial determinants of vote choice for large sections of the developing world, particularly in South Asia and Sub-Saharan Africa. Many scholars acknowledge that voters might have expressive preferences for co-ethnic candidates and parties (Horowitz 1985; Carlson 2015). 
Perhaps even more influential, however, is the belief that ethnicity can provide a useful heuristic for parties and voters to credibly support one another, thereby solving the commitment problems at the heart of discretionary distributive politics (Fearon 1999; Chandra 2004; Posner 2005).

Third, political parties in much of the developing world are characterized as relatively weak in organizational terms. They lack both strong norms that guide how power and responsibility flow internally as well as the organizational wherewithal to exert a meaningful presence in the daily lives of citizens between elections. Consequently, citizens are thought to attach to candidates rather than parties, which only reinforces the weak incentives for programmatic politics to develop. Parties mobilize to contest and win elections but fade into the distance once those elections conclude.

As the world's most populous—and the developing world's most enduring — democracy, India has provided both inspiration for, and validation of, these three stylized facts. First, India has widely been seen to characterize non-programmatic distributive politics. Indeed, the country has been dubbed as the epitome of a "patronage democracy". ${ }^{1}$ Second, India has long been invoked as an exemplar of an ethnicized democracy, with caste and religion structuring the vote (Kothari 1970; Chandra 2004). Finally, Indian political parties are largely described as institutionally weak, organizationally shallow, and overly personalistic (Kohli 1990; Keefer and Khemani 2004; Manor 2005).

${ }^{1}$ This term is defined by Chandra $(2004,6)$ as a democracy "in which the state has a relative monopoly on jobs and services, and in which elected officials enjoy significant discretion in the implementation of laws allocating the jobs and services at the disposal of the state." 
The objective of this article is to consider research on India that challenges the contention that India neatly fits the prevailing wisdom on each of the three issues highlighted abovedistributive politics, ethnic voting, and political parties. In so doing, it forces us to scrutinize afresh the very underpinnings of that conventional wisdom for research on developing countries more broadly. Thus, this article is not about how comparative politics can inform our understanding of India, but what India can teach us about how to reframe some of our core assumptions as comparativists. We also argue that the research highlighted here suggests scholars of comparative politics must be more prudent in how they invoke India to support their claims. To be clear, our aim is not to suggest that existing characterizations of India are wholly erroneous but rather to bring nuance to what we perceive to be the prevailing wisdom. Finally, we discuss some possible new research frontiers opened up by relaxing some of the standard assumptions that presently shape our thinking.

\section{Distributive Politics}

Over the past two decades, a burgeoning literature on distributive politics has modelled politician-voter linkages and their implications for the allocation of government-provided goods and services and politician-enabled election-time handouts (Golden and Min 2013). Scholars have analyzed politicians' decisions to allocate public resources across space (Dixit and Londregan 1996; Porto and Sanguinetti 2001; Arulampalam et al. 2009; Cammett and Issar 2010; Nathan 2019), their strategies over the distribution of private benefits between elections (Auyero 2000; Calvo and Murillo 2013; Diaz-Cayeros et al. 2016), as well as their decisions over the allocation of cash and other gifts during elections (Wantchekon 2003; Brusco et al. 2004; Schaffer 2007).

A major strand of the literature on distributive politics focuses on clientelism-iterative, 
quid-pro-quo relationships between politicians and voters in which access to goods and services is conditional on political support. ${ }^{2}$ Although research on clientelism is diverse (see Hicken 2011 for a review), much of this literature is based on four core assumptions about politician-voter relations: contingency, electoral timing, voter monitoring, and hierarchy in politician-voter interactions. In this section, we unpack these assumptions and reevaluate them in light of recent evidence from India.

\section{Core Assumptions}

First, clientelism revolves around contingent transactions. The implications of models that emphasize such contingency (Stokes 2005; Rueda 2016; Nichter 2018; Gans-Morse et al. 2014) are worth spelling out. If distributive politics is primarily about quid pro quo transactions, moral and programmatic elements should rarely guide allocation decisions and voters should infrequently choose candidates on the basis of programmatic promises.

Second, the transactions in question typically involve the distribution of targeted goods during elections - and research focused on this asks whether and how such efforts sway voters and boost turnout. Across diverse settings such as Argentina (Auyero 2000; Szwarcberg 2015), Brazil (Gay 1994), Hungary and Romania (Mares and Young 2019), India (Piliavsky 2014), and Kenya (Kramon 2016), it appears that communities are flooded with material inducements in the run-up to elections. An implicit assumption is that politicians expect to directly benefit from these efforts.

${ }^{2}$ While some work utilizes a broader conceptual understanding of clientelism (Kitschelt and Wilkinson 2007; Ziegfeld 2016), we refer here to work drawing on this narrower conception. 
Third, contingent transactions require local political actors who can facilitate distribution and observe voters' preferences with reasonable accuracy. Most analyses emphasize the existence of party networks enlisting brokers to carry out these quid pro quo transactions (Stokes 2005; Stokes et al. 2013; Camp 2015). In many studies, these party networks are modeled as relatively fixed, comprising long-term partisan actors. As a result, brokers - as in the quintessential Peronist example from Argentina - emerge as committed to a specific party network. Relatedly, the literature frequently relies on these brokers' ability to distinguish between core supporters and swing voters (Stokes 2005; Nichter 2008; Stokes et al. 2013). This assumption implies a partial failure of the secret ballot.

Fourth, models of clientelism also often emphasize hierarchy in politician-voter interactions - the ability of leaders to successfully wield the upper hand with voters, resulting in a power asymmetry in patron-client relations. The contingency at the heart of clientelism implies a form of "perverse accountability" that robs individuals of choice over their vote (Stokes 2005). The implications of this narrative are bleak for democratic politics.

\section{Prevailing Wisdom}

India has typically been assumed to exhibit these same characteristics. In fact, the country is frequently described as an archetypical "patronage democracy" in which the distribution of state services is discretionary, whether driven by electoral, material or cultural expectations (Bailey 1970; Chandra 2004; Chatterjee 2004; Piliavsky 2014), and where citizens often turn to intermediaries to help them navigate otherwise dismissive, capricious state institutions (Reddy and Haragopal 1985; Oldenburg 1987; Manor 2000; Corbridge et al. 2005; Harriss 2005). Thus, descriptions of non-programmatic politics, rent-seeking politicians, and porous state institutions 
have long been applied to India (Krueger 1974; Rudolph and Rudolph 1987; Bardhan 1998). Herring (1999), for instance, described how governance in India exhibits forms of "embedded particularism" wherein the actions of state officials are twisted to local political interests. Gupta (1995) described the "blurred lines" between state and society in India, highlighting the negotiated exchanges that unfold in local governance.

In such contexts, citizens can appeal to politicians to intervene in bureaucratic procedures and have the rules bent to advance their material interests (Berenschot 2010). Intermediaries proliferate in this environment to mediate access to state services and collect rents and patronage for such activities (Reddy and Haragopal 1985; Manor 2000; Krishna 2002; Mitra 2002). India is thus depicted as an "intermediated democracy" (Berenschot 2010), where individuals similar to the "brokers" at the center of the comparative literature on distributive politics abound (Bardhan et al. 2009).

New Approaches

Such strong evidence of local intermediation might lead observers to assume that India is a setting where we should observe many of the dynamics previously highlighted as central to clientelism. Yet, many studies of Indian politics upend several of the key assumptions embedded in the comparative literature.

First, the assumption of quid pro quo politics - particularly the ability of politicians or brokers to monitor voting behavior-is challenged by a robust secret ballot, meaningful voter autonomy, and substantial electoral volatility (Heath 2005; Uppal 2009). Indeed, one recent study in rural Rajasthan found that sarpanch (elected village officials) are not particularly competent in "guessing" the voting behavior of local villagers (Schneider 2019). Another study in an urban 
metropolitan setting (Mumbai) finds that brokers tasked with allocating election-time money for candidates do not even attempt to monitor votes (Chauchard 2018). Both suggest that the exchange of support for goods between voters, brokers, and patrons in India is probabilistic, at best. An evaluation of state legislator behavior by Bussell (2019) shows that politicians offer constituency service similar to what is observed in Global North democracies, without attention to contingency or partisan leanings.

Second, recent work suggests that the universe of intermediaries engaged in distributive politics is less partisan than what previous work suggests. Whereas party activists are often described as having strong and stable ties to parties in the Latin American context (Magaloni 2008; Stokes et al. 2013), recent work suggests the party-broker relationships in India are quite fluid. ${ }^{3}$ These actors are not just geographically proximate to voters but they are also embedded and active outside of elections, when their primary purpose is to help citizens access the state (Krishna 2002; Kruks-Wisner 2018). In addition to traditional party workers (Harriss 2005; Jha et al. 2007; Berenschot 2010; Auerbach 2020), middlemen can include entrepreneurial, non-partisan individuals who will work for the highest bidder (Manor 2000; Krishna 2002). These naya neta (new leaders) are thus often not expressly tied to any one political party (Krishna 2002).

The assumption that politicians inundate voters with handouts because they think it will swing elections also finds limited support. Studies of electoral handouts suggest that their impact is marginal and that politicians are well aware of these limitations (Björkman 2014; Chauchard 2018). For politicians, these efforts may instead be about revealing targeting preferences to voters

\footnotetext{
${ }^{3}$ Some scholarship on Latin America also suggests that local fixers are not necessarily partisan actors (Holland and Palmer-Rubin 2015).
} 
(Schneider and Sircar 2017), generating reputations for efficacy (Auerbach and Thachil 2018), signaling electoral viability or credibility regarding the promise of future transfers (Björkman 2014; Muñoz 2014) or simply seeming "glamorous" (Jensenius 2017).

Finally, research on Indian politics forces us to question the perception of voters as passive recipients of targeted goods (Stokes 2005; Nichter 2008). Recent research on Indian politics, however, finds substantial voter agency, often activated via bottom-up forms of organization and associational activity (Dasgupta 2017; Auerbach 2020). Voters often hedge their bets by diversifying their claim-making strategies (Kruks-Wisner 2018) and can circumvent nonresponsive politicians and officials in India's multi-tiered, federal democracy (Bussell 2019). As Bussell's work demonstrates, citizens who are "blocked" from accessing public services because they lack connections to local patronage networks often petition higher-level politicians who have an incentive to respond to their grievances in order to expand their personal following. Poor voters are also pivotal in the construction of patron-client hierarchies (Auerbach and Thachil 2018), challenging studies that see such networks as structures imposed from above (e.g. Calvo and Murillo 2013).

As a result of these findings, studies of Indian politics have pivoted away from examining episodic forms of "vote-buying" toward more quotidian forms of distributive politics (see Bussell 2012; Thachil 2014; Bohlken 2017; Dasgupta 2017; Bussell 2019; Auerbach 2020; Schneider 2020). The services being analyzed—roads, sewers, streetlights, and water taps—are politicized in their allocation and frequently involve networks of intermediaries. Yet, they are high-spillover goods, undermining the ability of politicians and brokers to exclude non-supporters. This suggests that politicians may be targeting groups or localities rather than individuals. In this respect, recent work more closely approximates the questions examined and findings unearthed during an earlier 
wave of research in Latin America (Ray 1969; Gay 1994). Moreover, these services are often provided not through election-time spending, but rather through everyday allocations that are harder to selectively withdraw than campaign handouts (Bussell 2019).

\section{Implications}

If the conventional wisdom in the scholarship on clientelism and patronage imperfectly applies to India, there are good reasons to question how well it applies to other contexts too, as argued in recent work on Latin America and Africa (see, e.g., Lawson and Greene 2014; Kramon 2016). This suggests that theories of distributive politics in developing countries need to be updated, expanded or nuanced. Specifically, we identify two potential avenues for future research.

First, research could explore variation in the roles and characteristics of brokers in mediating distribution. The depiction of the broker as a partisan activist embedded in a strongly organized machine is just one of many forms in which intermediaries emerge and operate. The Indian case suggests brokers need not be partisan activists in strongly organized machines, but rather may hedge their bets and refrain from investing in particular parties. New research should consider what types of actors have discretion over distribution and how this varies across contexts.

Second, another exciting avenue of research could explore patterns of allocation in contexts where partisanship and ethnicity have insufficient explanatory power. How does variation in citizen-level mobilization and claim-making strategies impact the chances of securing public services? And does variation along these lines lead to more just allocations of benefits, or perpetuate inequalities? Answering these questions will provide important insights into the ways in which citizens access the state and, crucially, the relative importance of agency in distributive politics. 


\section{Ethnic Voting}

While the study of clientelism has focused on how electoral incentives shape politicians' choices about the distribution of state resources, another extensive strand of literature has focused on the role of ethnic identity in shaping vote choice. While definitions of ethnicity can themselves be contentious (see Brubaker 2004; Chandra 2006), we follow broad convention in viewing ethnic groups as based on ascriptive categories such as race, tribe, religion or more subjectively as "selfidentification around a characteristic that is difficult or impossible to change, such as language, race, or location" (Birnir 2006, 66). Contributions from India to the study of ethnic politics have come from scholars of social movements (Baruah 1999; Jaffrelot 2003), identity formation (Pandey 1993; Chatterjee 2004), and violent conflict (Varshney 2002; Wilkinson 2004; Brass 2011). Given the focus of this essay, we focus here more narrowly on scholarship examining ethnic voting.

\section{Core Assumptions}

Theories of ethnic voting can be roughly partitioned into two camps: "expressive" and "instrumental" theories. ${ }^{4}$ Theories of expressive voting draw on social-psychological models of intergroup behavior, especially social identity theory, which predict in-group favoritism to manifest under even the most minimal of conditions (Tajfel and Turner 1986; Shayo 2009). Expressive theories anticipate that individuals in ethnically fragmented societies will seek affirmation of group self-worth by voting along ethnic lines (see Horowitz 1985). In the most

\footnotetext{
${ }^{4}$ This review could have been much longer. See Varshney (2007) for an excellent discussion of essentialist, instrumentalist, constructivists, and institutionalist views of ethnicity.
} 
extreme manifestations of this dynamic, elections will simply reflect the demographic strength of different groups.

In instrumental theories, ethnicity's political salience is explained as a consequence of its utility in maximizing anticipated access to material benefits. One influential set of arguments views ethnicity as an informational shortcut, or heuristic, in circumstances where voters have little information about a party's programmatic or distributive agenda. Sticky, visible ethnic markers are perceived as especially useful in solving commitment problems plaguing the discretionary exchange of goods for votes. Thus, voters support parties and candidates associated with their ethnic group, not because of a psychological attachment to their in-group, but because they see coethnics as their best chance of claiming state resources (Chandra 2004). Other models focus more on ethnicity's relative utility in crafting minimum winning coalitions (Posner 2005; Huber 2017). A third set of studies highlight the instrumental behavior of political elites, who sometimes deploy divisive campaign strategies intended to polarize ethnic divisions, in the hope of inducing ethnic voting (Wilkinson 2004; Ferree 2006, Nellis et al 2016). ${ }^{5}$ Instrumental models of ethnicity have quickly risen to prominence within the study of electoral behavior across the global South. ${ }^{6}$

\section{Prevailing Wisdom}

Whether interpreted as expressive or instrumental, ethnic voting is considered an important force molding electoral behavior in low-income, multi-ethnic democracies. India has been central to motivating and confirming this conventional wisdom. Pioneering scholarship on India's

\footnotetext{
${ }^{5}$ While Wilkinson $(2004,22-26)$ centrally examines variation in the incidence of ethnic conflict (specifically riots), his framework theorizes a link between ethnically polarizing campaign strategies and electoral behavior.

${ }^{6}$ For example, Carlson $(2015,355)$ argues that instrumentalist ethnic voting is "a foundational assumption of much of the current literature on African political behavior."
} 
postcolonial politics outlined how ethnic groups, especially caste groups, rapidly adapted to the imperatives of democratic politics (Kothari 1964; Weiner 2001; Shah 2004). Voters of the same localized sub-castes (jatis) were mobilized into electoral blocs or "vote banks" through various mechanisms. ${ }^{7}$ Caste-based associations swiftly transformed from traditional social organizations to vehicles for interest group politics - whether as a means to organize voters or to place demands on the state for greater welfare, educational, and economic development (Rudolph and Rudolph 1960). Localized caste-based voting blocs were integrated into multi-ethnic coalitions headed by powerful elites who delivered the votes of their bloc to the dominant party Indian National Congress (Srinivas 1955; Bailey 1970; Kothari and Maru 1970; Jaffrelot 2000). ${ }^{8}$

The nature of ethnic voting shifted in the competitive multiparty system that replaced Congress dominance. No longer content to be subsumed within upper caste-led factions, lower castes sought to aggregate local jatis of similar status into broader social blocs that could fuel their own political parties (Yadav 1999; Pai 2002; Michelutti 2008; Ahuja 2019). This "silent revolution" (Jaffrelot 2003) dramatically reshaped the social composition of the country's legislatures. In many Indian states, the faltering Congress was replaced by a fragmented set of regionalized political players seen to draw support from specific linguistic or caste communities (Ruparelia 2015; Ziegfeld 2016).

The political transformation of caste-based interests in the early years of Indian democracy can help us understand how the political salience of ethnic identities are activated and continually reshaped in a dynamic social and political context. In particular, the Indian experience informs our

\footnotetext{
${ }^{7}$ Jati is widely regarded as the most salient political category in India (see Shah 2006).

${ }^{8}$ Influential examples include Congress' "KHAM" coalition of four social groups (Kshatriyas, Harijans, Adivasis, and Muslims) in the 1980s, and the "Muslim-Yadav" alliance forged by the Samajwadi Party in Uttar Pradesh in the 1990s.
} 
comparative understanding of how a status-based system, similar to other ancien régime cases, adapts and finds new relevance. As Yadav $(1999,2398)$ notes: "politics has affected caste as much as caste affects politics." Some scholarship has theorized the microfoundations of ethnic voting in India. Chandra (2004) links ethnic voting to India's "patronage democracy," whereby stable and visible ethnic identities effectively structure clientelistic exchange. Consequently, voters choose parties with the highest "head counts" of leaders from their own ethnic group. ${ }^{9}$ Other accounts have emphasized the psychological benefits of descriptive representation, which especially fuel ethnic voting among low-status groups (Pai 2002). Beyond caste, scholars have argued that India's Muslims vote cohesively for particular types of parties and candidates, based on their overall demographic strength (Rudolph and Rudolph 1987, 195).

The importance of this long lineage of work is indisputable. These studies also highlight how identity interacts with various causal factors - political agency, institutional design, patronage, ideological conflicts, group size, and cross-cutting social cleavages - to explain political outcomes. Yet while these studies are individually nuanced in their explanations of ethnic voting, their collective weight often gives the impression that India is primarily characterized by ethnicized political behavior. As Herring $(2013,137)$ notes, many observers continue to describe Indian politics as "the moving about of blocks on a chess board - this caste supports X, this caste, Y, and so the election went." Ethnic voting can thus easily be construed as the past and present of Indian democracy. Importantly, studies of other parts of the world often invoke the example of

\footnotetext{
${ }^{9}$ Some studies of low-income democracies find that voters prioritize shared ethnicity with candidates, as opposed to parties (Posner 2005; Chauchard 2016).
} 
India as a paradigmatic example of a polity dominated by ethnic voting (Ferree 2006; Gao 2016; Ejdemyr, Kramon, and Robinson 2017).

\section{New Approaches}

Recent studies of Indian politics have challenged this stereotype. Beyond identifying variations in the electoral preferences of members of the same group as past studies have done, current scholarship has more centrally focused on the explanations for why such heterogeneity in within-group preferences emerges across states and time periods. Thachil (2014) analyzes the roots of variation in support from low-status ethnic groups in India for the Hindu nationalist party BJP, which has historically been identified as representing wealthy upper-caste Hindus. Suryanarayan (2019) explains variation in when economically disadvantaged members of the socially privileged upper castes support the BJP to retain their social dominance. Ahuja (2019) explores variation in the cohesion of voting among low caste Dalits and shows how it is more prevalent in states with weaker Dalit social movements; social mobilization of the marginalized, he argues, weakens ethnic voting because it makes other political parties co-opt their agenda. Heath, Vernier, and Kumar's (2015) work on electoral preferences among Muslims, long considered India's most cohesive ethnic vote bank, shows that Muslims only support co-ethnic candidates who have a realistic chance of winning. Devasher (2014) arrives at similar conclusions through an analysis of Muslim communities in Uttar Pradesh.

There is also increasing evidence of performance-based—or economic — voting in India (Verma 2012; Gupta and Panagariya 2014; Vaishnav and Swanson 2015). Cole et al. (2012) show that voters are less likely to punish the ruling coalition for weather emergencies when the government responds effectively to them. 
These findings in no way demonstrate that ethnicity is irrelevant in Indian politics. They do suggest, however, the need to view ethnicity as one of many factors influencing, rather than the central foundation of, political behavior in India. In fact, recent studies that explicitly compare the relative salience of ethnicity and non-ethnic indicators of efficacy, find the latter to be as-if not more-significant than the former. Chauchard (2016) draws on experimental data from Uttar Pradesh, widely regarded as a bastion of ethnic voting in India, to show that while ethnicity shapes voters' evaluations of hypothetical candidates, so does information about performance in office, knowledge about their criminal records, and overall party evaluation. At a more localized level, Auerbach and Thachil (2018) provide experimental evidence that poor urban slum residentsoften portrayed as prototypical ethnic voters - weigh markers of efficacy more strongly than shared ethnicity when selecting informal settlement leaders. Perhaps most starkly, Vaishnav (2017) finds that many voters in the northern state Bihar cannot even identify the caste of the politician for whom they voted just days after they cast their ballots.

\section{Implications}

The nuanced findings of early studies of Indian elections, further buttressed by more recent scholarship, cut against easy stereotypes of the country's voters as solely or even primarily motivated by ethnicity. Instead, this legacy suggests several openings for exciting research in India and beyond. The first is more studies of how parties and candidates develop cross-ethnic reputations for competence within developing democracies. For example, Power and Ready (2018) study how village leaders in Tamil Nadu construct reputations for generosity that help garner support from across caste lines. Such work can contribute to emerging comparative efforts on 
understanding dynamics of constituency service and credit claiming (see, e.g., Harding 2015), that have received less attention than theories of ethnic patronage.

Second, there is considerable potential to develop more nuanced frameworks acknowledging the interplay between class and ethnicity in multi-ethnic democracies. Conceptualizing vote choices as dichotomous - either ethnic/clientelistic or programmatic/classbased - is unnecessarily limiting. Models of ethnic voting rightly pushed back against spatial models that presumed the universality of a Western-style left-right programmatic axis. However, their critiques may have been too quick to abandon class entirely, neglecting the fact that class politics need not be conceptualized solely in terms of traditional tax-and-transfer policies.

Class can inform sectoral voter preferences and political mobilization strategies in economic policy, including in the realms of targeted subsidies, agricultural prices, and other policy agendas. Again, class and ethnic politics might intersect within such strategic efforts. Anderson et. al (2015) find that landlords from a locally dominant caste are able to wield their economic influence to ensure support for their preferred candidate from poor villagers of numerous, less privileged castes. Huber and Suryanarayan (2016) use group-wise caste and sub-caste voting patterns across Indian states to show that ethnic voting is greater in places with greater inter-group economic differences. In other words, there is a strong class component to ethnic voting in ways that echo the "ethnopopulism" witnessed in other parts of the world (Madrid 2012). Contemporary studies of earlier periods of Indian politics provide similarly intersectional insights. For example, Lee (2019) finds that levels of education within caste groups informs their degree of mobilization during British colonial rule, as measured by petitions for name changes submitted to the colonial government. 
Finally, where models of ethnic clientelism repeatedly emphasized the lack of ideological and programmatic politics in India, future efforts can help uncover where and when ideology matters, including in service of constructing multi-ethnic coalitions. Chhibber and Verma (2018) argue that citizens' views of who the state serves, and how it functions, have created ideological cleavages in Indian politics that cut across caste lines. The image of members of various ethnic groups joining in programmatic opposition to a rival coalition that includes their own co-ethnics is an exciting step in moving past depictions of Indian voters as mechanically assembling into caste-based vote banks.

\section{Political Parties}

Our third topic concerns the key building blocks of democratic elections: political parties. Much like parties across the developing world, Indian parties have been characterized as organizationally weak. Indeed, many Indian parties are weak according to traditional metrics. ${ }^{10}$ Yet emerging research amply demonstrates that they excel at two core functions: campaigning and connecting citizens to the state. These seemingly competing depictions can be reconciled by conceiving of parties as networks rather than as vertically integrated organizations. In other words, there is more than one way for a party to be "strong." This framework incorporates what we know about Indian parties into broader discussions of party strength and offer lessons for studies of political parties elsewhere.

Core Assumptions

${ }^{10}$ See Chhibber et al. (2014) on variation in party strength across Indian states and over time. 
In comparative politics, party organization conventionally consists of two elements: institutions and infrastructure. ${ }^{11}$ Institutions structure how power and responsibility are distributed within a party: the authority vested in particular positions and how these positions relate to one another. Party infrastructure, meanwhile, refers to a party's "brick and mortar" presence: its working offices, paid staff, stable elite membership, and financial assets. According to these criteria, a party is said to be strong when: a) clearly delineated and consistently enforced rules allocate power and responsibility within the party and formalize the party's relationship to civilsociety based affiliates (e.g., churches and labor unions); and b) the party boasts a widespread physical presence, has sufficient personnel, a stable cadre of candidates and leaders, and ample coffers. We dub this understanding of party strength the parties-as-organizations approach. It stipulates that parties are strong insofar as they resemble a vertically integrated firm, construed as a hierarchically-structured organization capable of producing all the inputs needed to achieve the organization's goals (Williamson 1971).

Against this ideal-type, scholars routinely portray parties active in the developing world as amorphous entities lacking serious organizational backbone (Lupu and Riedl 2013). The focal concept in this literature is party system institutionalization (Mainwaring and Scully 1995). Party systems are considered highly institutionalized when parties have strong roots in society, voters maintain strong attachments to parties, and political elites treat parties as legitimate political actors. According to this view, party systems in poorer countries often appear weakly institutionalized-

${ }^{11}$ See, for example, Duverger $(1954,40-71)$ on parties' internal organization and memberships and Mainwaring and Scully (1995) and Tavits (2013, 16-19) on what constitutes a strong party organization. 
marked by high degrees of electoral volatility and personalism and low degrees of ideological linkages between parties and voters (Mainwaring and Torcal 2006). Reviewing the state of the party system in the Philippines, Hicken $(2009,156)$ writes that parties "can be set up, merged with others, split, resurrected, regurgitated, reconstituted, renamed, repackaged, recycled or flushed down the toilet anytime" (156). Similar descriptions emerge from Latin America (Van Cott 2007; Calvo and Murillo 2013; Novaes 2018), sub-Saharan Africa (Riedl 2014, 215), and postcommunist Europe (Bielasiak 2002; Tavits 2005).

Exceptions to this pattern certainly exist. The relatively institutionalized party systems in Ghana (Riedl 2014) or Taiwan (Hicken and Kuhonta 2011) are prominent examples. Moreover, even if entire party systems are not well institutionalized, individual parties may be (Randall and Svåsand 2002). Brazil's PT, or Worker's Party, (Samuels 1999), as well as dominant parties in semi-authoritarian countries like Singapore, Malaysia, Indonesia, and Tanzania fall into this category (Smith 2005; Slater 2010). Nevertheless, these counterexamples do not undermine broader claims that political parties tend on the whole to be weak across the Global South.

\section{Prevailing Wisdom}

Judged by standard metrics employed in comparative politics, Indian political parties are undoubtedly weak, particularly compared to parties in other longstanding democracies. ${ }^{12}$ Most Indian parties are highly centralized and run autocratically by a single leader or family and their

\footnotetext{
${ }^{12}$ Using V-Dem's Party Institutionalization Index (v2xps_party), 21 of 25 longstanding democracies consistently had party systems rated as better institutionalized than India's between 1952 and 2019.
} 
close associates. Outside ruling cliques, titular officeholders within the party tend to wield minimal authority — a point brought out in Chandra's (2004) analysis of the Bahujan Samaj Party (BSP), Wyatt's (2009) description of party "entrepreneurs" in Tamil Nadu, and Hansen's (2001) ethnography of the Shiv Sena in Maharashtra. Transparent rules for candidate selection and intraparty promotions are either altogether absent or widely flouted (Roy 1965; Farooqui and Sridharan 2014). In terms of infrastructure, too, Indian parties appear hollow. Local party offices (at the district- or block-levels) either do not exist or remain shuttered outside of election time. Parties have few permanent staff members, and party switching among politicians is rampant (Kashyap 1970; Kamath 1985). Descriptions of numerous major parties emphasize the extent to which they are loosely organized collections of local notables or regional factions (Erdman 1967; Fickett 1976).

There are anomalous cases. For decades, India's main communist parties possessed the trappings of classically strong parties but they have proven electoral viable in just two major Indian states. ${ }^{13}$ The BJP's ties to a Hindu revivalist organization, the Rashtriya Swayamsevak Sangh (RSS), have provided the party with some measure of organizational presence (Andersen and Damle 1987; Graham 1990), although its organizational strength is often overstated (Manor 2005). Notably, India's former dominant party, the Indian National Congress, boasted an extensive nationwide organization and well-developed internal institutions in the immediate decades after independence (Weiner 1967), though this atrophied from the 1960s onward (Kohli 1990).

13 However, Ruud (1994) and Desai (2001) complicate this generalization of communist organizational strength. 
Amid this landscape of organizational torpor, two stylized features of India's partisan politics appear surprising. The first is that, come election time, Indian parties mobilize vast amounts of human and financial capital and launch vigorous campaigns requiring armies of volunteers on the ground (Banerjee 2014; Björkman 2014; Jha 2017; Palshikar et al. 2017). To illustrate, the ruling BJP reportedly hired one panna pramukh ("page leader," referring to a page of the voter list) for every 30 to 60 voters during the last two national election campaigns. Indeed, according to the 2014 Indian National Election Study, 61 percent of respondents reported that a member of a political campaign had come to their house to solicit their vote. ${ }^{14}$

The second surprising feature is the scale at which parties effectively intermediate between citizens and the state. State capacity is low in India. Accessing state services and critical social safety nets is hard for most citizens. Parties supply the critical link in this unpredictable environment. Voters habitually turn to elected officials - and the parties to which they belongfor assistance in navigating the central, state or local bureaucracy (Chopra 1996; Kruks-Wisner 2018), and distributive politics often occurs through partisan channels (Dunning and Nilekani 2013).

In short, Indian parties fall short when matched up against traditional notions of party strength, but nonetheless shine in performing at least two advanced tasks: waging vast election campaigns and advocating for citizens in front of the state in between elections. How can India's parties appear both weak and strong at the same time?

New Approaches

${ }^{14}$ See http://www.lokniti.org/pdf/All-India-Postpoll-2014-Survey-Findings.pdf. 
In lieu of the dominant parties-as-organizations paradigm, this discussion suggests that India's parties are better understood using a parties-as-networks approach. Rather than relying on formal, internal structures to achieve party goals, Indian parties typically contract out to informal social networks. According to our conceptualization, a strong party-as-network relies on a broad set of interconnected members endowed with extensive physical, financial, and human assets. A weak party-as-network, meanwhile, draws on a comparatively small network of activists, working in relative isolation with few formal assets. The informal, social-network basis of many Indian parties frequently enables efficacy in campaigning and citizen-responsiveness, even as it coexists with—and may in fact promote—a weak organizational structure.

To highlight the distinction between strong parties-as-organizations and strong parties-asnetworks, consider how these different types of strong parties campaign and connect citizens to the state. When parties rely on traditional organizations, they campaign using their permanent physical infrastructure. In the case of party machines, a cadre of loyal, partisan-committed brokers develops close relationships with citizens and seeks to extract state benefits on their behalf (Auyero 2000; Calvo and Murillo 2004).

Parties whose strength derives from informal social networks perform these functions differently. During election time, such parties campaign by mobilizing large, extant networksfor instance, groups of voters united by geography or kinship networks and often aligned with local (rather than partisan) brokers or intermediaries - that provide physical, financial, and human capital. Members' homes become de facto campaign offices; personal wealth finances election expenditures (Sircar 2018); and friends, family members, and other associates engage in assorted campaign activities. These "movable" assets are the lifeblood of election campaigns, but only 
because network members choose to deploy them; they are not resources attached exclusively to the party. A member can transfer her wealth or followers to another party if she so desires.

A strong party-as-network can also effectively champion citizens' material needs between elections. Citizens approach a party member for assistance, but select this "helper" more on the basis of social proximity than formal party attachment. Party members then transmit community demands upward via their parties (Auerbach 2020) and draw on the full menu of social ties available to them to address those demands (Bussell 2019).

The strong party-as-network is particularly adept at furthering citizens' interests in at least three ways. First, social networks transmit information to parties about citizens' needs at low cost because citizens can more readily approach an acquaintance from their social network rather than an unknown party functionary. Second, dense networks composed of many members allow party activists to exploit the wide range of contacts often necessary to extract goods from an illfunctioning bureaucracy. Third, because citizens can exert social pressure on party leaders with whom they are in close social proximity, such party brokers are highly accountable. ${ }^{15}$

\section{Implications}

The parties-as-networks conceptualization has several implications for future research in democracies where political parties have not followed the trajectories of Western Europe's mass parties. For one, the presence of strong parties-as-networks calls into question the conventional wisdom that party systems in much of the developing world are inchoate and unstable (Mainwaring and Torcal 2006). The perpetual state of political flux observed in India may mask a surprising degree of structure and order. Often, electoral volatility exists alongside considerable stability in

\footnotetext{
${ }^{15}$ Tsai (2007) makes a similar argument in the context of rural China.
} 
the groups of voters that vote with or against one another. Indeed, relative to countries in the developing world, India's party system exhibits considerable institutionalization. ${ }^{16}$ One potential strategy for measuring the strength of parties-as-networks in India and elsewhere may be to examine the extent to which certain types of voters - whether defined in ethnic, geographic or other terms - routinely align with or against other groups, even if the specific parties for whom they are voting might change over time.

Additionally, future research should explore how parties build and maintain strong networks. What resources do they use to attract social networks, and how do they retain the loyalty of such networks? Some strategies — whether selective material incentives, ethnicity, ideology or leadership charisma - may be more effective in attracting high-quality, committed workers, and instilling loyalty to the party brand. The broader party system might also inform how parties engage with their constituent networks, as parties operating in a highly competitive context may behave differently than in places where the party is electorally dominant.

\section{Conclusion}

Emerging research on electoral behavior in India challenges some of the received wisdom in the comparative politics literature and the way in which the Indian case is refracted through it. While theories of patronage politics, identity-based voting, and organizationally weak parties capture important aspects of politics in developing countries, the Indian experience helps illuminate that there is considerably more variation on each of these than we often acknowledge.

\footnotetext{
${ }^{16}$ According to V-Dem's Party Institutionalization Index, the party systems in most democracies outside of Western Europe and North America have long been less institutionalized than India's.
} 
With regards to distributive politics, new research suggests that brokers and politicians in India are highly constrained in their ability to monitor voters thanks to a large, heterogeneous electorate and the relative sanctity of the secret ballot. These constraints raise doubts about whether politicians and voters can genuinely engage in a contractual quid pro quo. Many of the brokers encountered in the Indian context, moreover, are not the canonical partisan intermediaries observed in contexts of Latin American party machines. The relatively weak and volatile partisan ties of these actors generate more fluidity in vertical political linkages than is typically described in analyses of distributive politics. Further, recent studies have documented Indian villages and urban neighborhoods as intensely competitive brokerage environments, wherein multiple intermediaries continually vie with each other for a local following — both within and across party lines. Significant voter agency, coupled with competitive local brokerage environments, leaves conventional models of rigid clientelism with diminished analytical purchase in the Indian context.

Recent studies of voting behavior in India, in turn, question the dominance of accepted narratives regarding ethnic voting. Ethnicity does not always neatly overlap with political preferences; in fact, some research suggests that ethnic groups in India are remarkably heterogeneous in the expression of their political preferences. Furthermore, the extent to which ethnicity emerges as salient in voting behavior is conditioned by other types of group characteristics such as economic or social standing. In some cases, ethnicity appears to take a backseat to other electoral considerations, such as the state of the economy-a sign that the retrospective economic voting model popular in advanced industrial democracies could be at play. Another mainstay of politics in well-established democracies-constituency service-is also highlighted as something politicians prioritize and voters reward during elections. 
Finally, recent studies concur with past assessments regarding the weak organizational foundations of Indian parties. However, they also question whether formal characteristics — central to the study of Western party systems - are the best metrics through which to assess the robustness of political organizations in developing countries. Research from India suggests that the tendency to measure party strength using metrics of legislative discipline or physical presence gives short shrift to alternative conceptions, such as viewing parties as rooted in social networks. Indian parties often rely on personal networks to achieve their core goals, which means that they outsource many core party functions to individuals who are not full-time party workers. This suggests that a more profitable way to study parties in India, and perhaps other developing democracies, is to examine the underlying strength of their associated social networks.

Our hope is that the findings and hypotheses discussed in the preceding pages will enrich the broader study of political behavior in the developing world. Not only does this research question the repeated invocation of India in comparative politics for arguments the country only imperfectly exemplifies, but it also suggests exciting new directions in the study of comparative politics. 


\section{Bibliography}

Ahuja, Amit. 2019. Mobilizing the Marginalized: Ethnic Parties without Ethnic Movements. New York: Oxford University Press.

Andersen, Walter K., and Damle, Sridhar D. 1987. The Brotherhood in Saffron: The Rashtriya Swayamsevak Sangh and Hindu Revivalism. Boulder, CO: Westview Press.

Anderson, Siwan, Patrick Francois and Ashok Kotwal. 2015. "Clientelism in Indian Villages." American Economic Review 105(6): 1780-1816.

Arulampalam, Wiji, Sugato Dasgupta, Amrita Dhillon, and Bhaskar Dutta. 2008. "Electoral Goals and Center-State Transfers.” Journal of Development Economics 88(1): 103-119.

Auerbach, Adam M. 2020. Demanding Development: The Politics of Public Goods Provision in India's Urban Slums. New York: Cambridge University Press.

Auerbach, Adam M. and Tariq Thachil. 2018. "How Clients Select Brokers: Competition and Choice in India’s Slums.” American Political Science Review 112(4): 775-791.

Auyero, Javier. 2000. "The Logic of Clientelism in Argentina: An Ethnographic Account." Latin American Research Review 35(3): 55-81.

Bailey, F. G. 1970. Politics and Social Change: Orissa in 1959. Berkeley: University of California Press.

Banerjee, Mukulika. 2014. Why India Votes? London: Routledge India.

Bardhan, Pranab. 1998. The Political Economy of Development in India. New York: Oxford University Press. 
Bardhan, Pranab, Sandip Mitra, Dilip Mookherjee, and Abhirup Sarkar. 2009. "Local Democracy and Clientelism: Implications for Political Stability in Rural West Bengal.” Economic and Political Weekly 44(9): 46-58.

Baruah, Sanjib. 1999. India Against Itself: Assam and the Politics of Nationality. Philadelphia: University of Pennsylvania Press.

Berenschot, Ward. 2010. "Everyday Mediation: The Politics of Public Service Delivery in Gujarat, India." Development and Change 45(1): 883-905.

Bielasiak, Jack. 2002.” The Institutionalization of Electoral and Party Systems in Postcommunist States." Comparative Politics 34(2): 189-210.

Birnir, Johanna. 2006. Ethnicity and Electoral Politics. New York: Cambridge University Press. Björkman, Lisa. 2014. “'You Can’t Buy a Vote': Meanings of Money in a Mumbai Election.” American Ethnologist 41(4): 617-634.

Bohlken, Anjali Thomas. 2017. Democratization from Above: The Logic of Local Democracy in the Developing World. New York: Cambridge University Press.

Brass, Paul. R. 2011. The Production of Hindu-Muslim Violence in Contemporary India. Seattle: University of Washington Press.

Brubaker, Rogers. 2004. Ethnicity Without Groups. Cambridge, MA: Harvard University Press.

Brusco, Valeria, Marcelo Nazareno, Susan Stokes. 2004. "Vote Buying in Argentina.” Latin American Research Review 39(2): 66-88.

Bussell, Jennifer. 2012. Corruption and Reform in India: Public Services in the Digital Age. New York: Cambridge University Press.

Bussell, Jennifer. 2019. Clients and Constituents: Political Responsiveness in Patronage Democracies. New York: Oxford University Press 
Calvo, Ernesto and Victoria Murillo. 2004. "Who Delivers? Partisan Clients in the Argentine Electoral Market.” American Journal of Political Science 48(4): 742-757.

Calvo, Ernesto and Victoria Murillo. 2013. "When Parties Meet Voters.” Comparative Political Studies 46(7): 851-882.

Cammett, Melani and Sukriti Issar. 2010. "Bricks and Mortar Clientelism.” World Politics 62(3): 381-421.

Camp, Edwin. 2015. “Cultivating Effective Brokers.” British Journal of Political Science 47(3): 521-543.

Carlson, Elizabeth. 2015. "Ethnic Voting and Accountability in Africa: A Choice Experiment in Uganda." World Politics 67(2): 353-385.

Chandra, Kanchan. 2004. Why Ethnic Parties Succeed: Patronage and Ethnic Head Counts in India. New York: Cambridge University Press.

Chandra, Kanchan. 2006. "What is Ethnic Identity and Does It Matter?” Annual Review of Political Science 9: 397-424.

Chatterjee, Partha. 2004. The Politics of the Governed: Reflections on Popular Politics in Most of the World. New York: Columbia University Press.

Chauchard, Simon. 2016. "Unpacking Ethnic Preferences: Theory and Micro-Level Evidence from North India.” Comparative Political Studies 49(2): 253-284.

Chauchard, Simon. 2018. "Electoral Handouts in Mumbai Elections: The Cost of Political Competition." Asian Survey 58(2): 341-364.

Chhibber, Pradeep, Francesca Jensenius, and Pavithra Suryanarayan. 2014. "Party Organization and Party Proliferation in India." Party Politics 20(4): 489-505.

Chhibber, Pradeep and Rahul Verma. 2018. Ideology and Identity: The Changing Party Systems 
of India. New Delhi: Oxford University Press.

Chopra, Vir. 1996. Marginal Players in Marginal Assemblies: The Indian MLA. New Delhi: Orient Longman.

Cole, Shawn, Andrew Healy and Eric Werker. 2012. "Do Voters Demand Responsive Governments? Evidence from Indian Disaster Relief.” Journal of Development Economics 97(2): 167-181.

Corbridge, Stuart, Glyn Williams, Manoj Srivastava, and Rene Veron. 2005. Seeing the State. New York: Cambridge University Press.

Dasgupta, Aditya. 2017. "Technological Change and Political Turnover: The Democratizing Effects of the Green Revolution in India." American Political Science Review 112(4): 918-938.

Desai, Manali. 2001. "Party Formation, Political Power, and the Capacity for Reform: Comparing Left Parties in Kerala and West Bengal, India.” Social Forces 80(1): 37-60. Devasher, Madhavi. 2014. "Masjid vs. Mandal: Ethnic and Cross-Ethnic Voting in India.” PhD dissertation, Department of Political Science, Yale University, New Haven, CT.

Diaz-Cayeros, Alberto, Federico Estévez, and Beatriz Magaloni. 2016. The Political Logic of Poverty Relief: Electoral Strategies and Social Policy in Mexico. New York: Cambridge University Press.

Dixit, Avinash and John Londregan. 1996. "The Determinants of Success of Special Interests in Redistributive Politics.” Journal of Politics 58(4): 1132-1155.

Dunning, Thad and Janhavi Nilekani. 2013. "Ethnic Quotas and Political Mobilization: Caste, Parties, and Distribution in Indian Village Councils." American Political Science Review 107(1): 35-56. 
Duverger, Maurice. 1917. Political Parties: Their Organization and Activity in the Modern State. London, Methuen; New York, Wiley [1954].

Ejdemyr, Simon, Eric Kramon, and Amanda Lea Robinson. 2017. "Segregation, Ethnic Favoritism, and the Strategic Targeting of Local Public Goods." Comparative Political Studies 51(9): 1111-1143

Erdman, Howard L. 1967. The Swatantra Party and Indian Conservatism. London: Cambridge University Press.

Farooqui, Adnan and E. Sridharan. 2014. "Incumbency, Internal Processes and Renomination in Indian Parties." Commonwealth \& Comparative Politics 52(1): 78-108.

Fearon, James D. 1999. “Why Ethnic Politics and 'Pork' Tend to Go Together.” Paper presented at the SSRC-MacArthur sponsored Conference on "Ethnic Politics and Democratic Stability," University of Chicago, May 21-23.

Ferree, Karen E. 2006. “Explaining South Africa's Racial Census.” Journal of Politics 68(4): 803-815.

Fickett, Lewis P., Jr. 1976. The Major Socialist Parties of India: A Study of Leftist Fragmentation. Syracuse: Maxwell School of Citizenship and Public Affairs.

Gans-Morse, Jordan, Sebastian Mazzuca, and Simeon Nichter. 2014. "Varieties of Clientelism: Machine Politics during Elections." American Journal of Political Science 58(2): 415432.

Gao, Eleanor. 2016. "Tribal Mobilization, Fragmented Groups, and Public Goods Provision in Jordan." Comparative Political Studies 49(10): 1372-1403

Gay, Robert. 1994. Popular Organization and Democracy in Rio de Janeiro. Philadelphia: Temple University Press. 
Golden, Miriam and Brian Min. 2013. "Distributive Politics Around the World." Annual Review of Political Science 16: 73-99.

Graham, Bruce. 1990. Hindu Nationalism and Indian Politics: The Origins and Development of the Bharatiya Jana Sangh. Cambridge, UK: Cambridge University Press.

Gupta, Akhil. 1995. "Blurred Boundaries.” American Ethnologist 22(2): 375-402.

Gupta, Poonam and Arvind Panagariya. 2014. Growth and Election Outcomes in a Developing Country. Economics \& Politics 26(2): 332-354.

Hansen, Thomas Blom. 2001. Wages of Violence: Naming and Identity in Postcolonial Bombay. Princeton: Princeton University Press.

Harding, Robin. 2015. “Attribution and Accountability: Voting for Roads in Ghana.” World Politics 67(4): 656-689.

Harriss, John. 2005. "Political Participation, Representation, and the Urban Poor." Economic and Political Weekly 40(11): 1041-1054.

Heath, Oliver. 2005. "Party Systems, Political Cleavages and Electoral Volatility in India: A State-Wise Analysis, 1998-1999.” Electoral Studies 24(2): 177-199.

Heath, Oliver, Gilles Verniers and Sanjay Kumar. 2015. “Do Muslim Voters Prefer Muslim Candidates? Co-religiosity and Voting Behaviour in India.” Electoral Studies 38: 10-18. Herring, Ronald. 1999. “Embedded Particularism: India’s Failed Developmental State.” In The Developmental State, ed. Meredith Woo-Cummings, 306-334. Ithaca: Cornell University Press.

Herring, Ronald. 2013. “Class Politics in India: Euphemization, Identity and Power.” In Routledge Handbook of Indian Politics, eds., Atul Kohli and Prerna Singh, 129-143. London: Routledge. 
Hicken, Allen. 2009. Building Party Systems in Developing Democracies. New York: Cambridge University Press.

Hicken, Allen. 2011. "Clientelism.” Annual Review of Political Science 14: 289-310.

Hicken, Allen and Erik Martinez Kuhonta. 2011. "Shadows from the Past: Party System Institutionalization in Asia." Comparative Political Studies 44(5): 572-597.

Holland, Alisha and Brian Palmer-Rubin. 2015. "Beyond the Machine." Comparative Political Studies 48(9): 1186-1223.

Horowitz, Donald L. 1985. Ethnic Groups in Conflict. Berkeley: University of California Press.

Huber, John D. 2017. Exclusion by Elections. New York: Cambridge University Press.

Huber, John D. and Pavithra Suryanarayan. 2016. "Ethnic Inequality and the Ethnification of Political Parties." World Politics 68(1): 149-188.

Jaffrelot, Christophe. 2000. "The Rise of the Other Backward Classes in the Hindi Belt." The Journal of Asian Studies 59(1): 86-108.

Jaffrelot, Christophe. 2003. India's Silent Revolution: The Rise of the Lower Castes in North India. New York: Columbia University Press.

Jensenius, Francesca. 2017. Social Justice Through Inclusion: The Consequences of Electoral Quotas in India. New York: Oxford University Press.

Jha, Prashant. 2017. How the BJP Wins. New Delhi: Juggernaut.

Jha, Saumitra, Vijayendra Rao and Michael Woolcock. 2007. "Governance in the Gullies." World Development 35(2): 230-246.

Kamath, P.M. 1985. "Politics of Defection in India in the 1980's." Asian Survey 25(10): 10391054. 
Kashyap, Subhash C. 1970. "The Politics of Defection: The Changing Contours of the Political Power Structure in State Politics in India.” Asian Survey 10(3): 195-208.

Keefer, Philip and Stuti Khemani. 2004. "Why do the Poor Receive Poor Services?” Economic and Political Weekly 39(9): 935-943.

Kitschelt, Herbert and Steven I. Wilkinson. 2007. Patrons, Clients and Policies: Patterns of Democratic Accountability and Political Competition. New York: Cambridge University Press.

Kohli, Atul. 1990. Democracy and Discontent: India's Growing Crisis of Governability. New York: Cambridge University Press.

Kothari, Rajni. 1964. “The Congress ‘System’ in India.” Asian Survey, 4(12): 1161-1173.

Kothari, Rajni, ed. 1970. Caste in Indian Politics. New Delhi: Orient Longman.

Kothari, Rajni and Rushikesh Maru. 1973. "Federating for Political Interests: The Kshatrias of Gujarat.” In Caste in Indian Politics, ed. Rajni Kothari, 70-101. New Delhi: Orient Longman.

Kramon, Eric. 2016. "Electoral Handouts as Information: Explaining Unmonitored Vote Buying." World Politics 68(3): 454-498.

Krishna, Anirudh. 2002. Active Social Capital. New York: Columbia University Press.

Krueger, Anne. 1974. “The Political Economy of the Rent-Seeking Society.” American Economic Review 64(3): 291-303.

Kruks-Wisner, Gabrielle. 2018. Claiming the State: Active Citizenship and Social Welfare in Rural India. New York: Cambridge University Press.

Lawson, Chappell and Kenneth Greene. 2014. "Making Clientelism Work: How Norms of Reciprocity Increase Voter Compliance." Comparative Politics 47(1): 61-77. 
Lee, Alexander. 2019. "The Origins of Ethnic Activism.” Journal of Race, Ethnicity, and Politics 4(1): 148-179.

Lupu, Noam and Rachel Beatty Riedl. 2013. "Political Parties and Uncertainty in Developing Democracies." Comparative Political Studies 46(1): 1339-1365.

Madrid, Raúl. 2012. The Rise of Ethnic Politics in Latin America. New York: Cambridge University Press.

Magaloni, Beatriz. 2008. Voting for Autocracy: Hegemonic Party Survival and its Demise in Mexico. New York: Cambridge University Press.

Mainwaring, Scott and Timothy Scully. 1995. Building Democratic Institutions: Party Systems in Latin America. Stanford: Stanford University Press.

Mainwaring, Scott and Mariano Torcal. 2006. "Party System Institutionalization and Party System Theory After the Third Wave of Democratization." In Handbook of Party Politics, eds. Richard S. Katz and William J. Crotty, 204-227. London: Sage Publications.

Manor, James. 2000. "Small-Time Fixers in India's States." Asian Survey 40(5): 816-835.

Manor, James. 2005. “In Part a Myth: The BJP's Organizational Strength.” In Coalition Politics and Hindu Nationalism, eds. Katherine Adeney and Lawrence Saez, 55-74. London: Routledge.

Mares, Isabela and Lauren Young. 2019. Conditionality and Coercion: Electoral Clientelism in Eastern Europe. New York: Oxford University Press.

Michelutti, Lucia. 2008. The Vernacularisation of Democracy: Politics, Caste, and Religion in India. New Delhi: Routledge. 
Mitra, Subrata. 2002. Power, Protest, and Participation: Local Elites and the Politics of Development in India. London: Routledge.

Munoz, Paula. 2014. “An Informational Theory of Campaign Clientelism: The Case of Peru.” Comparative Politics 47(1): 79-98.

Nathan, Noah. 2019. "Local Ethnic Geography, Expectations of Favoritism, and Voting in Urban Ghana." Comparative Political Studies 49(14): 1896-29.

Nellis, Gareth, Michael Weaver, and Steven Rosenzweig. 2016. "Do Parties Matter for Ethnic Violence? Evidence from India." Quarterly Journal of Political Science 11(3): 249-277.

Nichter, Simeon. 2008. "Vote Buying or Turnout Buying?” American Political Science Review 102(1): 19-31.

Nichter, Simeon. 2018. Votes for Survival. New York: Cambridge University Press.

Novaes, Lucas M. 2017. "Disloyal Brokers and Weak Parties.” American Journal of Political Science 62(1): 84-98.

Oldenburg, Philip. 1987. "Middlemen in Third-World Corruption.” World Politics 39(4): 508535.

Pai, Sudha. 2002. Dalit Assertion and the Unfinished Democratic Revolution: The Bahujan Samaj Party in Uttar Pradesh. New Delhi: Sage Publications India.

Palshikar, Suhas, Sanjay Kumar, and Sanjay Lodha, eds. 2017. Electoral Politics in India: The Resurgence of the Bharatiya Janata Party. New York: Routledge.

Pandey, Gyanendra, ed. 1993. Hindus and Others: The Question of Identity in India Today. New Delhi: Viking.

Piliavsky, Anastasia. 2014. Patronage as Politics in South Asia. New York: Cambridge University Press. 
Porto, Alberto and Pablo Sanguinetti. 2001. "Political Determinants of Intergovernmental Grants: Evidence from Argentina." Economics \& Politics 13(3): 237-256.

Posner, Daniel N. 2005. Institutions and Ethnic Politics in Africa. New York: Cambridge University Press.

Power, Eleanor A. and Elspeth Ready. 2018. "Building Bigness: Reputation, Prominence, and Social Capital in Rural South India." American Anthropologist 120(3): 444-459.

Randall, V. and L. Svåsand. 2002. "Political Parties and Democratic Consolidation in Africa." Democratization 9(3): 30-52.

Ray, Talton. 1969. Politics of the Barrios of Venezuela. Berkeley: University of California Press.

Reddy, G. Ram and G. Haragopal. 1985. “The Pyraveekar.” Asian Survey 25(11): 1148-1162.

Riedl, Rachel Beatty. 2014. Authoritarian Origins of Democratic Party Systems in Africa. New York: Cambridge University Press.

Roy, Ramashray. 1965. “Congress Party in Bihar.” PhD dissertation, Department of Politics, University of California-Berkeley, Berkeley, CA.

Rudolph, Lloyd I. and Susanne Hoeber Rudolph. 1960. "The Political Role of India's Caste Associations." Pacific Affairs 33(1): 5-22.

Rudolph, Lloyd I. and Susanne H. Rudolph. 1987. In Pursuit of Lakshmi: The Political Economy of the Indian State. Chicago: University of Chicago Press.

Rueda, Miguel. 2016. "Small Aggregates, Big Manipulation.” American Journal of Political Science 61(1): 163-77.

Ruparelia, Sanjay. 2015. Divided We Govern: Coalition Politics in Modern India. New York: Oxford University Press. 
Ruud, Arild Engelsen. 1994. "Land and Power: The Marxist Conquest of Rural Bengal.” Modern Asian Studies 28(2): 357-380.

Samuels, David 1999. "Incentives to Cultivate a Party Vote in Candidate-centric Electoral Systems." Comparative Political Studies 32(4): 487-518.

Schaffer, Frederic Charles, ed. 2007. Elections for Sale: The Causes and Consequences of Vote Buying. Boulder: Lynne Rienner Publishers.

Schneider, Mark. 2019. "Do Local Leaders Know Their Voters? A Test of Guessability in India." Electoral Studies 61.

Schneider, Mark. 2020. "The Discerning Voter: Party-Voter Linkages and Local Distribution Under Multilevel Governance." Party Politics 26, no. 2 (2020): 191-202.

Shah, A.M. 2006. The Grassroots of Democracy: Field Studies of Indian Elections. New Delhi: Permanent Black.

Shah, Ghanshyam, ed. 2004. Caste and Democratic Politics in India. New Delhi: Orient Blackswan.

Shayo, Moses. 2009. "A Model of Social Identity with an Application to Political Economy." American Political Science Review 103(2): 147-174.

Sircar, Neeanjan. 2018. "Money in Elections: The Role of Personal Wealth in Election Outcomes." In Cost of Democracy: Political Finance in India, eds. Devesh Kapur and Milan Vaishnav, 36-73. New Delhi: Oxford University Press.

Slater, Dan. 2010. Ordering Power: Contentious Politics and Authoritarian Leviathans in Southeast Asia. New York: Cambridge University Press.

Smith, Benjamin. 2005. "Life of the Party: The Origins of Regime Breakdown and Persistence under Single-Party Rule.” World Politics 57(3): 421-451. 
Srinivas, M. N. 1955. India's Villages. Bombay: Asia Publishing House.

Stokes, Susan. 2005. "Perverse Accountability.” American Political Science Review 99(3): $315-$ 325.

Stokes, Susan C., Thad Dunning, Marcelo Nazareno, and Valeria Brusco. 2013. Brokers, Voters, and Clientelism. Cambridge: Cambridge University Press.

Suryanarayan, Pavithra. 2019. "When Do the Poor Vote for the Right Wing and Why: Status Hierarchy and Vote Choice in the Indian States." Comparative Political Studies 52(2): 209-245.

Szwarcberg, Mariela. 2015. Mobilizing Poor Voters: Machine Politics, Clientelism, and Social Networks in Argentina. New York: Cambridge University Press.

Tajfel, Henri and John C. Turner. 1986. "The Social Identity Theory of Intergroup Behavior." Psychology of Intergroup Relations 5: 7-24.

Tavits, Margit. 2005. “The Development of Stable Party Support: Electoral Dynamics in PostCommunist Europe.” American Journal of Political Science 49(2): 283-298.

Tavits, Margit. 2013. Post-Communist Democracies and Party Organization. New York: Cambridge University Press.

Thachil, Tariq. 2014. Elite Parties, Poor Voters: How Social Services Win Votes in India. New York: Cambridge University Press.

Tsai, Lily L. 2007. Accountability Without Democracy: Solidary Groups and Public Goods Provision in Rural China. New York: Cambridge University Press.

Uppal, Yogesh. 2009. "The Disadvantaged Incumbents: Estimating incumbency Effects in Indian State Legislatures." Public Choice, 138(1/2), 9-27. 
Vaishnav, Milan and Reedy Swanson. 2015. "Does Good Economics Make for Good Politics? Evidence from Indian States.” India Review 14(3): 279-311.

Vaishnav, Milan. 2017. "Ethnic Identifiability in India: Evidence from a Voter Survey.” Asian Survey 57(4): 738-763.

Van Cott, Donna Lee. 2007. From Movements to Parties in Latin America. New York: Cambridge University Press.

Varshney, Ashutosh. 2002. Ethnic Conflict and Civic Life: Hindus and Muslims in India. New Haven: Yale University Press.

Varshney, Ashutosh. 2007. "Ethnicity and Ethnic Conflict.” In The Oxford Handbook of Comparative Politics, eds. Carles Boix and Susan C. Stokes, 274-294.

Verma, Rahul. 2012. "What Determines Electoral Outcomes in India? Caste, Class, or Voters' Satisfaction with Government Performance?” Asian Survey 52(2): 270-97.

Wantchekon, Leonard. 2003. "Clientelism and Voting Behavior: Evidence from a Field Experiment in Benin.” World Politics 55(3): 399-422.

Weiner, Myron. 1967. Party Building in a New Nation: The Indian National Congress. Chicago: University of Chicago Press.

Weiner, Myron. 2001. “The Struggle for Equality: Caste in Indian Politics," in The Success of India's Democracy, ed. Atul Kohli, 193-225. New York: Cambridge University Press.

Wilkinson, Steven. 2004. Votes and Violence: Electoral Competition and Ethnic Riots in India. New York: Cambridge University Press.

Williamson, Oliver. 1971. "The Vertical Integration of Production." American Economic Review 61(2): 112-123. 
Wyatt, Andrew. 2009. Party System Change in South India: Political Entrepreneurs, Patterns and Processes. New York: Routledge.

Yadav, Yogendra. 1999. "Electoral Parties in the Time of Change." Economic and Political Weekly 34(34/35): 2393-2399.

Ziegfeld, Adam. 2016. Why Regional Parties? Clientelism, Elites, and the Indian Party System. New York: Cambridge University Press. 